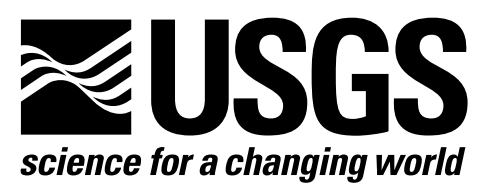

\title{
Developing an Analytical Framework: Incorporating Ecosystem Services into Decision Making - Proceedings of a Workshop
}

By Dianna Hogan, Greg Arthaud, Malka Pattison, Roger Sayre, and Carl Shapiro

Proceedings of a workshop associated with

A Conference on Ecosystem Services (ACES 2008)

July 28, 2008

Open-File Report 2009-1259 


\section{U.S. Department of the Interior \\ KEN SALAZAR, Secretary \\ U.S. Geological Survey \\ Marcia K. McNutt, Director}

U.S. Geological Survey, Reston, Virginia: 2010

For more information on the USGS - the Federal source for science about the Earth, its natural and living resources, natural hazards, and the environment, visit http://www.usgs.gov or call 1-888-ASK-USGS

For an overview of USGS information products, including maps, imagery, and publications, visit http://www.usgs.gov/pubprod

Any use of trade, product, or firm names is for descriptive purposes only and does not imply endorsement by the U.S. Government.

Although this report is in the public domain, permission must be secured from the individual copyright owners to reproduce any copyrighted materials contained within this report.

Suggested citation:

Hogan, Dianna, Arthaud, Greg, Pattison, Malka, Sayre, Roger, and Shapiro, Carl, 2010, Developing an Analytical Framework: Incorporating Ecosystem Services into Decision Making—Proceedings of a workshop: U.S. Geological Survey Open-File Report 2009-1259, 6 p. (Also available at http://pubs.usgs.gov/of/2009/1259/.) 


\section{Contents}

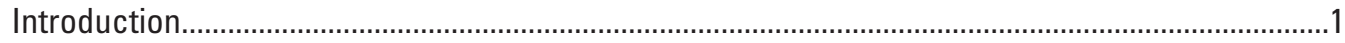

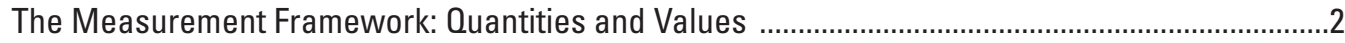

The Spatial Framework: Mapping and Spatial Relationships .........................................................3

Synthesis: Integrating the Spatial and Measurement Frameworks ..................................................3

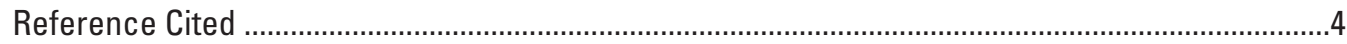

Appendix 1. Participants in Preconference Workshop 2, Developing an Analytical Framework: Incorporating Ecosystem Services into Decision Making ...................................................5 


\title{
Developing an Analytical Framework: Incorporating Ecosystem Services into Decision Making-Proceedings of a Workshop
}

\author{
By Dianna Hogan, ${ }^{1}$ Greg Arthaud, ${ }^{2}$ Malka Pattison, ${ }^{3}$ Roger Sayre, ${ }^{1}$ and Carl Shapiro ${ }^{1}$
}

This workshop was hosted by the Greater Everglades Ecosystem Restoration (GEER) 2008 Conference Naples, FL, July 28, 2008

In association with

A Conference on Ecosystem Services (ACES)

ACES 2008: Using Science for Decision Making in Dynamic Systems

\section{Introduction}

The analytical framework for understanding ecosystem services in conservation, resource management, and development decisions is multidisciplinary, encompassing a combination of the natural and social sciences. This report ${ }^{4}$ summarizes a workshop on "Developing an Analytical Framework: Incorporating Ecosystem Services into Decision Making," which focused on the analytical process and on identifying research priorities for assessing ecosystem services, their production and use, their spatial and temporal characteristics, their relationship with natural systems, and their interdependencies. Attendees discussed research directions and solutions to key challenges in developing the analytical framework. The discussion was divided into two sessions: (1) the measurement framework: quantities and values, and (2) the spatial framework: mapping and spatial relationships.

This workshop was the second of three preconference workshops associated with ACES 2008 (A Conference on Ecosystem Services): Using Science for Decision Making in Dynamic Systems. These three workshops were designed to explore the ACES 2008 theme on decision making and how the concept of ecosystem services can be more effectively incorporated into conservation, restoration, resource management, and development decisions. Preconference workshop 1, "Developing a Vision: Incorporating Ecosystem Services into Decision Making," was held on April 15, 2008, in Cambridge, MA (Hogan and others, 2009). In preconference workshop 1, participants addressed what would have to happen to make ecosystem services be used more routinely and effectively in conservation, restoration, resource management, and development decisions, and they identified some key challenges in developing the analytical framework. Preconference workshop 3, "Developing an Institutional Framework: Incorporating Ecosystem Services into Decision Making," was held on October 30, 2008, in Albuquerque, NM; participants examined the relationship between the institutional framework and the use of ecosystem services in decision making.

\footnotetext{
${ }^{1}$ U.S. Geological Survey, Reston, VA.

${ }^{2}$ U.S. Forest Service, Washington, DC.

${ }^{3}$ U.S. Department of the Interior, Washington, DC.

${ }^{4}$ The ideas presented in this report are based on contributions from participants at the workshop. Workshop participants are listed in appendix 1.
} 


\section{The Measurement Framework: Quantities and Values}

Interdisciplinary expertise is crucial for defining the measurement framework to best reflect the mix of ecosystem services, quantities, values, and science that are most appropriate to inform decision makers and other stakeholders. Interdisciplinary skills including economics, other social sciences, and the natural and physical sciences are needed to frame the issues, to identify the ecosystem services for inclusion, and to determine how to measure, value, and map the services. This approach allows issues, options, and values to be communicated across disciplines to facilitate information collection and analysis and better meet decision makers' needs. A first step is to identify the objectives of pending decisions, the decision makers and stakeholders, and the ecosystem services of concern. Different assessment and analytical approaches might be necessary to support different resource management issues.

The selection of ecosystem service metrics should reflect input from decision makers and stakeholders to ensure that the decision makers and the public are vested in the decision and the process of identifying and valuing ecosystem services. Proactive baseline monitoring of community preferences (for example, through focus groups, valuation surveys, or ethnographic or qualitative methods) may help to identify ecosystem services and how they are valued by the public. Each project should explicitly identify the issues, options, monitoring techniques, and decision process to be used. An effective approach would facilitate the consideration of ecosystem services and may foster the effective use of adaptive management, a structured approach to decision making that could accelerate the learning process and reduce uncertainty.

Interrelated ecosystem services, such as forest processes that provide water filtration, soil formation, carbon sequestration, and habitat, are sometimes bundled or integrated. Bundling may be organized or defined by ecosystem components (such as surface water, groundwater, or species type and abundance), structure, and (or) function (biological, chemical, and physical interactions among ecosystem components). The goal of bundling is to understand the interrelationships among ecosystem services and the cumulative effect of management actions. However, the terms and concepts are not clearly defined or consistently used, resulting in confusion and possible double counting of benefits. Identifying distinct and yet interrelated ecosystem services is scale dependent, and it may be difficult to bundle and then unbundle ecosystem services for analysis and interpretation. In addition, ecosystem supporting services (such as soil formation and nutrient cycling) may not be easily valued independently of other related services (such as carbon sequestration and water filtration).

Many, if not most, ecosystem services and affected stakeholders extend beyond typical geopolitical boundaries. For example, carbon sequestration and water filtration and stakeholders with an interest in providing and consuming the benefits of these services cross geopolitical boundaries, and the scope of the issues creates measurement and institutional challenges. These services and related stakeholders can also change at different spatial and temporal scales. For instance, increasing forestation may add to carbon sequestration, but that benefit would not be apparent at a local level. Scale is very relevant to the consideration of ecosystem services.

The Millennium Ecosystem Assessment provided a typology of four basic categories for ecosystem services that is widely used. However, there is no standardization of either the categories or the types of ecosystem services. Developing a common lexicon would enable diverse disciplines to communicate more effectively.

With respect to valuation of ecosystem services, using monetary units (dollars) of measurement is not always possible. Even when it is, monetization offends some stakeholders. Other societal or non-economic valuation techniques may be useful. Research is needed to develop additional valuation frameworks and metrics. The use of indicators may be needed for ecosystem service values that cannot be measured. For example, in the Pacific Northwest, forest productivity, rather than specific spotted owl values, is evaluated to measure the flow of ecosystem services. Providing quantified information on ecosystem services is an effective way to define a common metric to evaluate and communicate relative values and the tradeoffs associated with alternative management options.

Despite the challenges, economists, geographers, ecologists, and other scientists, cooperating in interdisciplinary teams, can work toward achieving the following goals to help establish a measurement framework for ecosystem services:

1. Establish baseline conditions from which to measure and model changes in ecosystem services.

2. Develop improved methods and models to identify, assess, and predict ecosystem service provision, flow, and value.

3. Improve information available to decision makers by incorporating science, uncertainty, and the ability to incorporate new data and analyses.

4. Identify and clearly communicate with uncertainty the tradeoffs of alternative management scenarios for ecosystem services.

5. Determine the (opportunity) costs and benefits of ecosystem services under alternative management scenarios. 
6. Incorporate uncertainty, risk, and time horizons into alternative management scenarios.

7. Use valuation approaches in a structured, iterative process to identify and aggregate ecosystem service values.

8. Explore the use of markets and other institutions to improve the flow of ecosystem services.

9. Evaluate the advantages and disadvantages of an array of regulatory and market-based strategies.

10. Identify how incentives affect outcomes.

\section{The Spatial Framework: Mapping and Spatial Relationships}

Mapping ecosystem services can improve the communication of relevant information to identify resource management options and achieve conservation objectives. Geospatial modeling and analysis of ecosystem services and their values have the potential to address ecological, spatial/temporal, and economic complexities by integrating spatially explicit data and models from ecology, economics, and other disciplines. This integration allows visualization and analysis of the distribution of the types, quantities, and values of ecosystem services and the impact of management actions. In this section, we explore ecosystem service map source information, what scales are most appropriate, how to account for temporal and spatial variations in ecosystem service production and use, and the question of the use of standard accounting units.

Developing ecosystem service maps depends on data availability, the mapping objectives of the target audience, and the required geographic and temporal scale(s) (that is, local, regional, or national level stakeholders and decision makers and longterm vs. short-term objectives). Potential data layers include ecosystem maps, land use/land cover assessments, environmental inventories, extant raw and derived data, resource ownership, and values (for example, stakeholder values or existence values). This information may be used as the basis for generating spatially explicit alternative futures (for example, future land use maps) and numerous qualitative or quantitative evaluations that may provide input to ecosystem service models. The models may, in turn, be used in tradeoff analyses to identify the effect of alternative management strategies on ecosystem services, economic performance, and social, cultural, and other quality-of-life values.

The resolution or scale at which ecosystem services should be mapped to facilitate use in decision making depends on the management issue, the affected stakeholders, and the regulatory or legal requirements. Analyses may be conducted at local, regional, national, or global scales. Tailoring geographic analyses to inform specific management decisions may require data integration from a variety of different spatial scales.

Accounting for ecosystem services production and use in any given geospatial unit may be difficult. Assessing trends in ecological processes and estimating ecosystem service production and consumption require spatially complex analyses accounting for spatial dependencies and temporal variability. A pilot or prototype study is recommended before developing very large (for example, national) ecosystem service assessments. The institutional complexities and scientific uncertainty increase dramatically with global assessments, as would be appropriate for carbon sequestration.

Geospatial units such as watersheds, ecosystems, ecoregions, and grid cells are used to assess and report ecosystem service status and trends. Using a standard geospatial unit could facilitate analyses and the transferability of results. However, there is no general agreement on which geospatial unit is best. The choice of a specific geospatial unit may be both decision- and application-specific. Research is necessary to evaluate the utility and fitness of alternative geospatial accounting units for different types and assessments of ecosystem services. There are differing opinions on whether this knowledge should emerge slowly from experience or be proactively developed (commissioned). Data and definitional standards are likely to emerge over time with experimentation and innovation.

\section{Synthesis: Integrating the Spatial and Measurement Frameworks}

This preconference workshop focused on the analytical framework for understanding and using ecosystem services in conservation, resource management, and development decisions. The analytical process requires a close integration and increased dialogue between the natural and social sciences and among decision makers, scientists, and stakeholders. To be successful, the effort will have to be interdisciplinary. The workshop participants identified a number of key issues and research priorities related to the quantification of ecosystem service production, spatial and temporal characteristics and interdependencies, and valuation. 


\section{Developing an Analytical Framework: Incorporating Ecosystem Services into Decision Making}

Key findings from the workshop include the following:

1. Communication across disciplines is difficult. The problem is not so much disagreement as miscommunication. A common vocabulary and set of definitions are needed. A glossary of terms would provide a good start in this direction.

2. In spite of communications difficulty, there is a need for the disparate disciplines to work together.

3. We need to work with a broad group of stakeholders to understand ecosystem services for decision making. Understanding ecosystem services, their quantities and values, and spatial relationships is not something that can be done in isolation from communities and decision makers. Metrics must reflect stakeholder input to be useful for decision making.

4. Understanding the relationship among ecosystem services and across geopolitical boundaries creates measurement and institutional challenges.

5. Standard units of account are important; however, it is difficult to reach consensus on specific measurement or geographic units of account.

6. The resolution and scale of spatial data required for an assessment of ecosystem services depend on the decision being addressed and the spatial extent of the issue. There is no single resolution or scale that is appropriate for decisions; however, the resolution or scale that is used affects the measurement of ecosystem service benefits.

7. Bundling is needed to consider the interrelationship among ecosystem services and the cumulative effect of management actions.

8. Ecosystem services provide a common metric for evaluating alternative management actions or decisions.

\section{Reference Cited}

Hogan, Dianna, Arthaud, Greg, Goodman, Iris, Pattison, Malka, Sayre, Roger, Shapiro, Carl, and Van Horne, Bea, 2009, Developing a Vision; Incorporating Ecosystem Services into Decision Making_Proceedings of a workshop: U.S. Geological Survey Open-File Report 2009-1062, 8 p., available online at http://pubs.usgs.gov/of/2009/1062/. 


\section{Appendix 1. Participants in Preconference Workshop 2, Developing an Analytical Framework: Incorporating Ecosystem Services into Decision Making}

Greg Arthaud, Acting National Program Leader: Economics Research, U.S. Forest Service, Washington, DC

Rich Bernknopf, Economist, U.S. Geological Survey, Menlo Park, CA

Gregory Biddinger, Natural Land Management Program Coordinator, ExxonMobil Biomedical Sciences, Inc., Houston, TX

Bernard Bormann, Research Team Leader, Ecosystem Processes Program, U.S. Forest Service, Corvallis, OR

Michael Bowers, National Program Leader, Ecology, Cooperative State Research, Education, \& Extension Service, U.S. Department of Agriculture, Washington, DC

David Brookshire, Professor and Director of Science Impact Laboratory for Policy and Economics, University of New Mexico, Albuquerque, NM

James Caudill, Senior Economist, Division of Economics, U.S. Fish and Wildlife Service, Arlington, VA

Tom Cecere, Land Remote Sensing Requirements Coordinator, U.S. Geological Survey, Reston, VA

Michael Flaxman, Asst. Professor of Urban Information Systems, Department of Urban Studies and Planning, Massachusetts Institute of Technology (MIT), Cambridge, MA

Tom Gunther, Program Coordinator, USGS Enterprise Information, and Project Lead for Data Integration and Interoperability, U.S. Geological Survey, Reston, VA

Tim Hayden, Program Manager, U.S. Army Corps of Engineers (USACE), Champaign, IL

Jim Henderson, Environmental Planner, U.S. Army Engineer Research and Development Center, U.S. Army Corps of Engineers, Vicksburg, MS

Dianna Hogan, Research Physical Scientist, U.S. Geological Survey, Reston, VA

Herman Karl, Co-Director, MIT-USGS Science Impact Collaborative (MUSIC), and Visiting Lecturer Massachusetts Institute of Technology (MIT), Department of Urban Studies and Planning, Cambridge, MA

Bill Labiosa, Research Physical Scientist, U.S. Geological Survey, Menlo Park, CA

Timothy Lewis, Chief, Aquatic Ecology and Invasive Species Branch Environmental Laboratory, U.S. Army Corps of Engineers, Vicksburg, MS

Kent Loftin, President, SynInt, Inc., Hobe Sound, FL

James Newman, Fire Planner, Bureau of Land Management, Sacramento, CA

Malka Pattison, Program Analyst, Office of Policy Analysis, U.S. Department of the Interior, Washington, DC

Barry Rosen, Director, Florida Integrated Science Center, U.S. Geological Survey, Orlando, FL

Roger Sayre, Senior Scientist, Geographic Analysis and Monitoring Program, U.S. Geological Survey, Reston, VA

Darius Semmens, Research Physical Scientist, U.S. Geological Survey, Denver, CO

Carl Shapiro, Senior Advisor, Geography Discipline, U.S. Geological Survey, Reston, VA

Benjamin Simon, Economist, Acting Assistant Director, Office of Policy Analysis, U.S. Department of the Interior, Washington, $\mathrm{DC}$

David Strong, Physical Scientist, U.S. Geological Survey, Reston, VA

Stephen Swallow, Professor, Environmental and Natural Resource Economics, University of Rhode Island, Kingston, RI 
Steve Traxler, Senior Fish and Wildlife Biologist, U.S. Fish and Wildlife Service, Vero Beach, FL

Nathalie Valette-Silver, National Ocean Service Director for the Cooperative Center for Marine Animal Health, National Oceanic and Atmospheric Administration, Silver Spring, MD

Jim Wickham, Senior Research Biologist, National Exposure Research Laboratory, U.S. Environmental Protection Agency, Raleigh, NC

Rob Winthrop, Senior Social Scientist, Decision Support, Planning, and National Environmental Policy Act (NEPA), Bureau of Land Management, Washington, DC

David Yoskowitz, Research Associate, Harte Research Institute for Gulf of Mexico Studies and Associate Professor of Economics-College of Business, Texas A\&M University, Corpus Christi, TX

Erik Zobrist, Science Program Team Leader, National Oceanic and Atmospheric Administration Restoration Center, Silver Spring, MD 